Szymon Wierzbiński (Łódź)

\title{
Prospective Gain or Actual Cost? Arab Civilian and Military Captives in the Light of Byzantine Narrative Sources and Military Manuals FROM THE $10^{\text {TH }}$ CENTURY
}

It is safe to say that the $10^{\text {th }}$ century was a military renaissance for the Byzantines. During this period, the Eastern Empire waged numerous wars, broadened its boundaries and regained much of its formerly lost prestige. For the Byzantine emperors of the $10^{\text {th }}$ century, the eastern front was the crucial one, due to the constant struggle with the Abbasid Caliphate ${ }^{1}$. In the course of this conflict - from which Byzantium emerged victorious - the capturing and enslaving of soldiers and civilians alike was an everyday reality. The main objective of this paper is to define the role of prisoners of war in the strategy and tactics of Byzantine generals. First, I will attempt to determine whether the latter treated the captives as a potential gain under various aspects (i.e. financial, prestige-related, or diplomatic). Next, I will focus on those situations in which prisoners were nothing more than a burden. With the help of narrative sources and military manuals, I will try to clarify why both sides occasionally decided to execute their captives in certain episodes of the $10^{\text {th }}$ century Arab-Byzantine conflict. Finally, I will specify how Byzantine generals made use of prisoners in order to get the upper hand over their Arab rivals. It should be emphasized that the present research was carried out mainly on the basis of the written sources. Since the period in question is well documented, I will focus on the Arab-Byzantine conflict only.

Byzantine written sources leave no doubt that the generals of the Empire, as a rule, tried to take prisoners during the campaigns in northern Syria ${ }^{2}$. The process

\footnotetext{
${ }^{1}$ During the period in question, most of the military operations were concentrated within the eastern frontier of Byzantium, which was called the thughür by the Arabs, M. Bonner, The Naming of the Frontier: Awāșim, Thughūr, and the Arab Geographers, BSOAS 57, 1994, p. 17-24; A.A. EgER, Islamic Frontiers, Real and Imagined, AUAW 17, 2005, p. 1-6. As noted by K. NAKADA, the ongoing war with the Arabs was in fact one of the crucial concerns of the emperors (The Taktika of Leo VI and the Byzantine Eastern Frontier During the Ninth and Tenth Centuries, SOJ 1, 2017, p. 17-27).

${ }^{2}$ The struggle was greatly enhanced by the pacification of the Paulician fortress of Tephrike in 872 AD, W. Treadgold, A History of the Byzantine State and Society, Stanford 1997, p. 457; K. NAKAdA,
} 
is quite evident especially in the second half of the $10^{\text {th }}$ century, when the defense of Islam rested on the emirs of Aleppo and Mosul. However, during the first decades of the period under discussion, it was the Arabs who ravaged the eastern border of Byzantium more often ${ }^{3}$ (at that time, the most prominent enemy of the Empire was the emirate of Tarsus). In the first years of Leo VI's rule, the Arabs captured Hypsele 4 . As pointed out by Warren Treadgold, in the years 896-898 the Byzantine territory was raided each year and major settlements or fortresses were taken (Kars, Corum in Cappadocia and most of the Theme of the Cibyrrhaeots ${ }^{5}$ ). Also during Leo's reign, the Arabs sacked Samos and took Constantine Paspa-

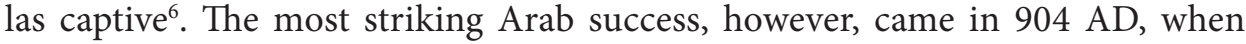
Leo of Tripolis captured Thessalonica ${ }^{7}$. Taking advantage of the internal problems of the Byzantines as well as the Bulgarian threat, the emirs of Melitene and Tyr ravaged the Byzantine borderlands between 916 and $918^{8}$. Due to the upcoming war with the Bulgarians, empress Zoe decided to sign a truce with the Arabs, although it seems that the warlike rulers took it lightly ${ }^{9}$. The streak of luck for the Arabs came to an end with the ascension of Romanus I Lecapenus to the throne and John

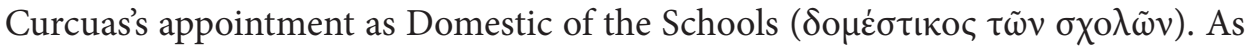

The Taktika..., p. 22. From then on, both the Arabs and the Byzantines fought for domination over the bordering emirates and other contested lands.

${ }^{3}$ After the defeat suffered during the campaign of $960 \mathrm{AD}$, the Arabs were under constant pressure, so that the roles in fact changed: while at the beginning of $10^{\text {th }}$ century the Arabs would repeatedly breach the Byzantine border for loot and slaves, during the reign of Romanus II the Empire began a swift reconquest. It is worth mentioning that most of the above-described military operations were focused within one region, namely the Cilician plain, M. Bonner, The Naming..., p. 17; K. Durak, Traffic across the Cilician Frontier in the Ninth and Tenth Centuries: Movement of People between Byzantium and the Islamic Near East in the Early Middle Ages, [in:] Proceedings of the International Symposium Byzantium and the Arab World. Encounter of Civilizations. (Thessaloniki, 16-18 December 2011), ed. A. Kralides, A. Gkoutzioukostas, Thessaloniki 2013, p. 141.

${ }^{4}$ Ioannis Scylitzae Synopsis historiarum, 4, 94-96, ed. H. Thurn, Berolini 1973 [= CFHB, 5] (cetera: Scylitzes), p. 172; Theophanes Continuatus, VI, 4, 11-15, ed. I. Bekker, Bonnae-Lipsiae 1838 [= CSHB, 31] (cetera: Theophanes Continuatus), p. 354.

${ }^{5}$ W. Treadgold, A History..., p. 465-466. It seems that the Arabs followed certain preferred directions in their campaigns, K. NAKADA, The Taktika..., p. 20. According to some scholars, the military operations were accompanied by a strong religious and ideological component. As pointed out by A. Asa Eger, the reason for this might have been the semi-nomadic transhumance of the Arabs and the rivalry for land suitable for pastoralism, A.A. EGER, Islamic..., p. 1-2.

${ }^{6}$ SCylitzes, 9, 64-65, p. 175; Theophanes Continuatus, VI, 7, 3-4, p. 357.

${ }^{7}$ SCylitzes, 23, 66-69, p. 183; Theophanes Continuatus, VI, 20, 1-5, p. 368.

${ }^{8}$ Scylitzes, 7, 67-70, p. 202; Theophanes Continuatus, VI, 9, 5-12, p. 388; G. Ostrogorski, Dzieje Bizancjum, trans. ed. H. Evert-Kappesowa, ${ }^{3}$ Warszawa 2008, p. 270-271; W. Treadgold, A History..., p. 474-475.

${ }^{9}$ Scylitzes, 8, 71-76, p. 202-203; Theophanes Continuatus, VI, 10, 13-17, p. 388; Kronika Leona Gramatyka, [in:] TNDS.SG, V, Pisarze $z X$ wieku, trans. et ed. A. Brzóstкowska, Warszawa 2009 [= PSla, 127] (cetera: Leo Grammaticus), p. 81. 
a result, it was not until 948/949 when Sayf al-Dawla organized another large-scale expedition against the Empire, at a time when Constantine Porphyrogennetus had sent an army to recover Crete $^{10}$. In $950 \mathrm{AD}$, too, the emir campaigned on the eastern border of Byzantium, though during his return he was ambushed by Leo Phocas and sustained heavy casualties ${ }^{11}$. A short period of prosperity came for the Arabs during the years 952-955, when Bardas Phocas held the post of Domestic of the Schools ${ }^{12}$. In $956 \mathrm{AD}$, the Hamdanid army attacked the Empire once again and although Sayf managed to defeat the then inexperienced John Tzimiskes, in the meantime Leo Phocas captured the emir's cousin near Aleppo ${ }^{13}$. The Arabs tried their luck once more in the year 960 (while the Byzantines were busy conquering Crete), but they were repulsed with heavy losses near Adrassos ${ }^{14}$. Although the campaigns were no longer a threat to Empire's integrity, the Muslims would plunder the border themes for slaves and booty, not infrequently year after year.

Of course, the Byzantines did not limit themselves to mere defense; they undertook numerous attempts to harass the aggressor's territory ${ }^{15}$. In fact, it is worth mentioning that they were at times not satisfied with the mere ravaging the land of their enemies, but also tried to claim it for good. Thus, the reconquest of northern Syria from the hands of the Muslims started during the reign of Basil the Macedonian on a rather modest scale, only to end with the capture of Antioch by Nicephorus II Phocas and John Tzimiskes's campaigns less than a century later ${ }^{16}$. The weakness of the Abbaside Caliphate and the Byzantines' overcoming their internal problems resulted in a more aggressive approach toward the Arabs. Consequently, towards the end of the $9^{\text {th }}$ century Basil I undertook two campaigns against them ${ }^{17}$. Several years later, the Byzantines under Domestic of the Schools Andrew defeated the emir of Tarsus, with both Theophanes Continuatus and Scylitzes pointing out that he had gained many victories against the Arabs even before ${ }^{18}$. One should

\footnotetext{
${ }^{10}$ W. Treadgold, A History..., p. 486; Scylitzes, 15, 33-35, p. 245-246.

${ }^{11}$ Scylitzes, 9, 41-46, p. 240-242; John Skylitzes, A Synopsis of Byzantine History, 811-1057, trans. J. WORTLEY, Cambridge 2010, p. 234, an. 42.

${ }^{12}$ W. Treadgold, A History..., p. 492; Scylitzes, 9, 5-14, p. 240-241.

${ }^{13}$ Scylitzes, 9, 18-22, p. 241; M. McCormick, Eternal Victory. Triumphal Rulership in Late Antiquity, Byzantium and the Early Medieval West, Cambridge 1986 [= PP.P], p. 159-160; A. RAMAdAN, The Treatment of Arab Prisoners of War in Byzantium, $9^{\text {th }} 10^{\text {th }}$ Centuries, AIs 43, 2009, p. 178.

${ }^{14}$ Scylitzes, 4, 52-57, p. 250; Theophanes Continuatus, VI, 14, 18-22, 1, p. 479-480.

${ }^{15}$ In these cases, the campaigns were mostly conducted by the domestics, while in the case of defensive operations, the command was given to the local strategoi, K. NAKADA, The Taktika..., p. 20-21. ${ }^{16}$ For the consequences for the Cilician plain see A.A. EgER, Islamic..., p. 5-6.

${ }^{17}$ Theophanes Continuatus mentions both of them, the first in the year 873 and the second in 878 $\mathrm{AD}$, Chronographiae quae Theophanis Continuati nomine fertur Liber V quo Vita Basilii Imperatoris amplectitur, 39-40; 46, ed. I. ŠEvčEnko, Berlin-Boston 2011 [= CFHB, 42] (cetera: Theophanes (ŠEVČENKO); this edition does not include book VI; as a result, in most cases I consulted the edition from the year 1838), p. 141-147, 165-167.

${ }^{18}$ Theophanes (Š́včenko), V, 50, p. 179-185; Scylitzes, 24, 23-25, p. 143-144.
} 
stress that, in the period under discussion, the Empire was concerned with the consolidation of power in the new territories as well as with strengthening the alliances with the Armenians. Thus, taking prisoners was, as a rule, an additional gain in the event of victory. This was probably the case in the two campaigns undertaken by Leo VII in 901 and $902 \mathrm{AD}^{19}$. Two years later, the emperor sent Eustathius Argyrus and Andronicus Ducas to acquire captives in order to exchange them for the imprisoned citizens of Thessalonica ${ }^{20}$. Some years later, in 911 AD, Leo made his final and unsuccessful attempt to reconquer Crete $^{21}$. The internal struggle for the imperial throne as well as the Bulgarian incursions onto the Byzantine territory caused the Empire to lower the pace of the war with the Arabs ${ }^{22}$. However, the situation improved after the ascension of Romanus I Lecapenus to the throne and John Curcuas's appointment as Domestic of the Schools. First, he managed to capture (albeit briefly) the emirate of Melitene, between 926-927 AD ${ }^{23}$. Eventually, the seat of the Muslim state was taken in $934 \mathrm{AD}$ by Curcuas and Melias, the strategos of the Theme of Lycandus; only those willing to become Christians were allowed to stay ${ }^{24}$. The fortune also favored Curcuas later: the apogee of his success were the campaigns from the years 942-944. The domestic besieged Edessa so efficiently that its citizens were forced to ask for peace and returned the sacred mandylion ${ }^{25}$. Theophanes stresses that Curcuas achieved numerous victories and took many prisoners, although he exaggerates somewhat when crediting him with the conquest of the whole Syria ${ }^{26}$. In the year 948, Bardas Phocas captured Adata and it is likely that he took prisoners during this operation ${ }^{27}$. However, the first years after Curcuas's dismissal were rather difficult for the Empire, due to Sayf al-Dawla's dominance over the new domestic. The Byzantines' luck turned again after the post had been taken by Nicephorus Phocas, Bardas's son. When the emir of Aleppo attacked the Byzantine frontier, Leo Phocas captured his cousin Abu'lAsha'ir in $956 \mathrm{AD}^{28}$. Two years later, the Byzantines took Samosata ${ }^{29}$. One of the

\footnotetext{
${ }^{19}$ A.A. VAsiliev, Byzance et les Arabes, vol. II, La Dynastie macédonienne, 867-959, Bruxelles 1950, p. 141-144; W. Treadgold, A History..., p. 466.

${ }^{20}$ SCyLitzes, 24, 83-86, p. 183.

${ }^{21}$ Scylitzes, 33, 7-8, p. 191; Theophanes Continuatus, VI, 31, 23, 1-4, p. 376-377.

${ }^{22}$ However, one should note that even in those difficult periods, the Empire managed to achieve some success, such as the defeat of Leo of Tripolis in 922 AD, Scylitzes, 11, 4-8, p. 218; Theophanes Continuatus, VI, 14, 11-16, p. 405.

${ }^{23}$ Scylitzes, 19, 69-71, p. 224; Theophanes Continuatus, VI, 24, 8-12, p. 416.

${ }^{24}$ W. Treadgold, A History ..., p. 481.

${ }^{25}$ Scylitzes, 37, 66-70, p. 231-232; Theophanes Continuatus, VI, 48, 4-11, p. 432.

${ }^{26}$ Scylitzes, 32, 31-33, p. 230; Theophanes Continuatus, VI, 24, 10-16, p. 415; VI, 40, 25, 1-4, p. $426-427$.

${ }^{27}$ SCylitzes, 15, 33-35, p. 245.

${ }^{28}$ Scylitzes, 9, 18-20, p. 241; M. McCormick, Eternal..., p. 159-160; A. Ramadan, The Treatment..., p. 178.

${ }^{29}$ Theophanes Continuatus, VI, 44, 11-17, p. 461-462.
} 
greatest successes, however, was the conquest of Crete as a result of the campaign that took place 960-961 AD $^{30}$. Knowing that Sayf al-Dawla was preparing an attack, Nicephorus Phocas anticipated the aggression and struck in 962 AD. As we are told by Scylitzes, the Byzantines took most of Aleppo except for the cita$\operatorname{del}^{31}$; likewise, Bar Hebraeus informs us that Nicephorus took many prisoners ${ }^{32}$. From this moment onwards, the Hamdanid power was clearly broken, so that both Nicephorus II Phocas and John Tzimiskes conquered new territories in the years that followed. Among the many accomplishments, one should mention particularly the taking of Mopsuestia and Tarsus in $965 \mathrm{AD}^{33}$. As remarked by Leo the Deacon, all inhabitants of the former city who survived the siege were taken into captivity $^{34}$. Eventually, in the year 969, the Byzantines conquered Antioch ${ }^{35}$. During the reign of John Tzimiskes, too, the Byzantine armies campaigned in Syria, acquiring loot and prisoners. This applies especially to the period after the war with the Bulgarians, i.e. 972-975 ${ }^{36}$. Particularly noteworthy is Leo the Deacon's account of the campaign of the years 972-974. It is likely that Tzimiskes ravaged the emirate of Mosul during this period, which would have surely resulted in the taking of many captives ${ }^{37}$. Although it is still disputed what the extent of Tzimiskes's conquest was, it is relatively uncontroversial that he campaigned in 972, 974 and $975 \mathrm{AD}^{38}$ (that being said, certain scholars contend that there is no sufficient proof that the campaign from the year 974 really took place $\left.{ }^{39}\right)$.

One can observe at least two regularities that characterize the period under discussion. Firstly, between the enthronement of Leo VI the Wise in 886 AD and the coronation of Nicephorus II in 963 AD, most of the campaigns were conducted

\footnotetext{
${ }^{30}$ Leonis Diaconi Caloensis Historiae Libri Decem, II, 7, ed. C.B. Hase, Bonnae 1828 [= CSHB, 3] (cetera: Leo the Deacon (Hase)); The History of Leo the Deacon. Byzantine Military Expansion in the Tenth Century, II, 7, trans. et ed. A.-M. Talbot, D.F. Sullivan, Washington 2005 [= DOS, 41] (cetera: Leo the Deacon (trans.)), p. 78-79; SCylitzes, 4, 52-57, p. 250.

${ }^{31}$ Scylitzes, 10, 24-29, p. 252-253.

${ }^{32}$ The Chronography of Gregory Abu'l Faraj 1225-1286, the Son of Aaron, the Hebrew Physician, Commonly Known as Bar Hebraeus, X, trans. E.A. WAllis Budge, Amsterdam 1976 (cetera: BAR HeBRAEUS), p. 168.

${ }^{33}$ Histoire de Yahya-ibn-Sa'ïd d'Antioche, continuateur de Sa'̈̈d-ibn-Bitriq, ed. et trans. I. Кratchkovsky, A. Vasiliev, Paris 1924 [= PO, 18.5] (cetera: Yahya), p. 795-796; Scylitzes, 12, 20-23, p. $268-269$.

${ }^{34}$ Leo the Deacon (Hase), III, 10-11; Leo the Deacon (trans.), p. 101-102.

${ }^{35}$ Leo the Deacon (Hase), V, 4-5; Leo the Deacon (trans.), p. 132-134; Scylitzes, 17, 27-31, p. 271-273; YAHYA, p. 823.

${ }^{36}$ W. Treadgold, A History..., p. 511-512.

${ }^{37}$ Leo the Deacon (Hase), X, 2; Leo the Deacon (trans.), p. 202-205. Finally, in 975 AD, the emperor captured Baalbek (which he described in a letter to his ally Ashot III), Chronique de Matthieu d'Édesse (962-1136) avec la Continuation de Grégoire le prêtre jusqu'en 1162, trans. E. Dulaurier, Paris 1858 , p. 16-24.

${ }^{38}$ A.-M. Talbot, D.F. Sullivan, Introduction, [in:] The History of Leo the Deacon..., p. 22.

${ }^{39}$ A. Kaldellis, Did Ioannes I Tzimiskes Campaign in the East in 974?, B 84, 2014, p. 235-240.
} 
by officials or generals designated by the basileus. Unsurprisingly, most of latter were military leaders in the rank of Domestic of the Schools ${ }^{40}$. The other salient feature of the Arab-Byzantine conflict in the $10^{\text {th }}$ century was the presence of frequent temporary truces, negotiated by both sides in times of internal conflicts or in the case of external threats ${ }^{41}$. This is one of the main reasons why the struggle between the vast Byzantine empire and the small but valiant Arab border emirates of the Abbasid Caliphate continued for so long ${ }^{42}$.

Throughout this conflict, both sides were eager to take prisoners, although not for the same reasons. Sometimes, as in the case of Hypsele (captured by the Arabs in the first years of the reign of Leo the Wise) or the sack of Thessalonica (by Leo of Tripolis), the main aim of the attackers was to acquire slaves and booty ${ }^{43}$. In other cases, such as in $916 \mathrm{AD}$, the generals were given orders to campaign on enemy territory in order to capture civilians destined to be exchanged for Byzantine captives ${ }^{44}$. These three examples prove that while taking prisoners was sometimes a mere additional objective for the army, at other times it could be a priority ${ }^{45}$. Thus, the value of the prisoners would differ, depending on the campaign's main objective. In this respect, it is worth considering how the matter of taking captives was perceived by Byzantine generals.

\section{The symbolic significance of Arab captives in Byzantium - cost for the general, gain for the Empire?}

As can be seen from the above, the Arab-Byzantine conflict was quite prolonged. During its course, both sides searched for various ways to get the upper hand. In this connection, it seems clear that Arab prisoners of war played an important role in the Byzantine propaganda of success. Among the many ways in which the Empire sought to demonstrate the superiority of its military power, there was one ceremony that held a unique place in the cultural heritage of its citizens. The

\footnotetext{
${ }^{40}$ A. Kazhdan, Domestikos ton scholon, [in:] ODB, vol. I, p. 647-648; T.C. Lounghis, The Decline of the Opsikian Domesticates and the Rise of the Domesticate of the Scholae, B $\Sigma u \mu 10,1996$, p. 27-36.

${ }^{41}$ This was the case in $917 \mathrm{AD}$, when empress Zoe strove to contain the threat posed by Tsar Symeon and needed all the power she could gather. The same applies to the situation from 932/933, when Romanus Lecapenus intended to pacify the mutiny along the eastern borders of the Empire: SCYLitzes, 8, 71-76, p. 202-203; G. Ostrogorski, Dzieje..., p. 265-266; W. Treadgold, A History..., p. 474,481 .

${ }^{42}$ K. Durak, Traffic..., p. 142-143.

${ }^{43}$ Scylitzes relates that in Hypsele the Arabs took all inhabitants into captivity, while in the case of Thessalonica only half of the citizens were taken prisoner, Scylitzes, 4, 94-96, p. 172; 23, 66-69, p. 183.

${ }^{44}$ This was probably the case in the campaigns undertaken by Eustathius Argyrus and Andronicus Ducas, Scylitzes, 24, 83-86, p. 183; W. Treadgold, A History..., p. 467.

${ }^{45}$ Bar Hebraeus claims that the Byzantines captured some 50000 people in Tarsus and Marash, BAR Hebraeus, X, p. 156.
} 
spectacle in question, inherited from the times of the Roman Empire, was the tri$\mathrm{umph}^{46}$. An integral part of it was a parade of the victorious emperors and commanders alongside the captured enemies. The ceremony itself took place in the hippodrome of Constantinople and was meant to uphold the Byzantine identity, including the affinity with the Roman Empire. Since the role of the triumph was so prominent, the authors of written (mainly narrative) sources mention it on many occasions ${ }^{47}$. As regards the $10^{\text {th }}$ century, one of the most interesting descriptions of the ceremony comes from Constantine Porphyrogennetus ${ }^{48}$. Apart from him, another Byzantine statesman who experienced the honor of triumph (at least once) was John Curcuas ${ }^{49}$. The ceremony also took place after the victories of Nicephorus II Phocas and his brother Leo Phocas, as well as their relative John Tzimiskes ${ }^{50}$.

As mentioned before, the Byzantines considered themselves Romans (in the sense of the Greek-Byzantine self-designation'P $\omega \mu$ aĩol - Rhōmaîoi). What is more, organizing a parade displaying the captive Arabs - the arch-enemies of the Byzantines - was designed to demonstrate the superiority of the Christian arms as well as to bolster the cultural identity of Byzantium as the heir of the Roman Empire ${ }^{51}$.

\footnotetext{
${ }^{46}$ There is a vast literature on this topic, although the discussion has been centered on the religious aspects of the ceremony, M. MCCoRMick, Eternal..., p. 110-111.

${ }^{47}$ The importance of the triumph is seen just as clearly in sources from earlier periods as well. One of such examples can be found in the anonymous treatise on strategy, most likely composed sometime in the $6^{\text {th }}$ century, perhaps during the reign of Justinian, De Re Strategica, 3, 101-107, [in:] Three Byzantine Military Treatises, trans. et ed. G.T. Dennis, Washington 1985 [= DOT, 9] (cetera: De Re Strategica), p. 18-19.

${ }^{48}$ Constantine Porphyrogenitus, Three Treatises on Imperial Military Expeditions, ed. et trans. J.F. Haldon, Wien 1990 [= CFHB, 28] (cetera: Three Treatises), p. 141-143, 149; W. Treadgold, A History..., p. 459. The emperor gives a most detailed description of Basil I's triumph in $879 \mathrm{AD}$, held together with his son Constantine.

${ }^{49}$ The first triumph probably took place after the final defeat of the emirate of Melitene, probably around $934 \mathrm{AD}$ (Theophanes Continuatus, VI, 24, 23, 1-2, p. 415-416). Curcuas was awarded the second triumph in $944 \mathrm{AD}$, not long before his dismissal from the post of Domestic of the Schools. Both Theophanes Continuatus and Scylitzes indicate that it was a reward not only for the military victory but also for securing the Mandylion (Scylitzes, 32, 26-30, p. 230; 37, 70-72, p. 231-232; Theophanes Continuatus, VI, 48, 4-11, p. 432). Note also W. Treadgold, A History..., p. 479-481.

${ }^{50}$ Nicephorus Phocas - after conquering Crete in 961 AD (Leo the Deacon (Hase), II, 8; Leo the DeAcon (trans.), p. 79-81) and after the campaign resulting in the conquest of Mopsuestia and Tarsus in 965 AD (Scylitzes, 16, 64-71, p. 271; Leo the Deacon (Hase), IV, 4; Leo the Deacon (trans.), p. 109); Leo Phocas - in 956 AD after capturing Sayf al-Dawla's cousin (Scylitzes, 9, 18-22, p. 241), in $960 \mathrm{AD}$ after fending off the latter's offensive near Adrassus (Leo the Deacon (HASE), II, 4; Leo the Deacon (trans.), p. 75; Scylitzes, 4, 53-58, p. 309-310; W. Treadgold, A History..., p. 509), and in $974 \mathrm{AD}$ after defeating the Arabs of Mosul (Leo the Deacon (Hase), X, 2; Leo the Deacon (trans.), p. 204; W. Treadgold, A History..., p. 511).

${ }^{51}$ Another interesting custom with a strong symbolic meaning was the presence of different groups of barbarians near the emperor, D.C. Sмy THE, Why Do Barbarians Stand Round the Emperor at Diplomatic Receptions?, [in:] Byzantine Diplomacy. Papers from the Twenty-fourth Spring Symposium of Byzantine Studies, Cambridge, March 1990, ed. J.S. ShePard, S. FrankLIN, Aldershot 1992 [= SPBSP, 1], p. 305-306, 311-312.
} 
Hence, the presence of the captives (representing the loathed Abbasid Caliphate) was clearly an indispensable element ${ }^{52}$. The sources at our disposal allow us to presume that in some cases the victorious Byzantine commanders' agenda was to make sure that at least some of Arab prisoners would live long enough to participate in the triumph. According to Leo the Deacon, the above-mentioned procedure was followed by Nicephorus II Phocas after his conquest of Crete ${ }^{53}$. The author leaves no doubt that the future emperor separated the chosen prisoners from the rest of the booty meant for the army because he intended to organize a triumph in Constantinople.

The presence of Arab prisoners of war during the triumph was also desired when the commanders of the Empire succeeded in routing the invasion of the Hamdanid army in the Byzantine territory. The reason is that the struggle against the warlike emir of Aleppo, Sayf al-Dawla, in the second half of $10^{\text {th }}$ century was a particularly intense and bloody one, so that both sides resorted to ideology and religion in their respective narratives ${ }^{54}$. A unique triumph took place after Leo Phocas's victory over Sayf al-Dawla in $960 \mathrm{AD}$, as we are informed by Leo the Dea$\operatorname{con}^{55}$. The success was memorable, as Leo Phocas managed to set free the Christians taken captive by the emir of Aleppo at the earlier stages of his campaign. This was truly a notable achievement, considering the fact that ten years earlier the commander had not been able to prevent the slaughter of prisoners at the hands of the Arabs, although he had defeated the emir ${ }^{56}$. What is more, Sayf al-Dawla's army was utterly annihilated; almost two years passed before he managed to muster a new one. In his chronicle, John Scylitzes claims that it was impossible to count how many enemies had perished during the battle, and that the Byzantines took

\footnotetext{
${ }^{52}$ As pointed out by Liliana Simeonova, during the ceremonies in question the Byzantines would not only humiliate the Arab prisoners in many ways, but also torture some of their animals, such as horses (In the Depths of Tenth-century Byzantine Ceremonial: the Treatment of Arab Prisoners of War at Imperial Banquets, BMGS 22, 1998, p. 75). Moreover, Jakub SYPIAŃski notes that - in view of the sophisticated culture of the Arabs - it was not only religion that was challenged, but also imperial ideology (Arabo-Byzantine Relations in the $9^{\text {th }}$ and $10^{\text {th }}$ Centuries as an Area of Cultural Rivalry, [in:] Proceedings..., p. 465).

${ }^{53}$ Leo the Deacon (Hase), II, 8; Leo the Deacon (trans.), p. 79-80; L. Simeonova, In the Depths..., p. 100-101.

${ }^{54}$ It is worth mentioning that the Arabs played an important role not only during the Byzantine triumphs, but also in other situations. As a Christian ruler, the emperor would utilize the Muslim prisoners in various events at the court, involving semi-baptismal ceremonies, L. Simeonova, In the Depths..., p. 76.

${ }^{55}$ The success must have been perceived as quite illustrious, since it is mentioned by Theophanes Continuatus (Theophanes Continuatus, VI, 14, 10-12, p. 480), John Scylitzes (Scylitzes, 4, 52-57, p. 250) and Leo the Deacon (Leo the Deacon (Hase), II, 5; Leo the Deacon (trans.), p. 75-76). ${ }^{56}$ Leo the Deacon (Hase), II, 5; Leo the Deacon (trans.), p. 75. As we mentioned, a decade earlier the Byzantines could only watch as Sayf al-Dawla butchered the captives before pulling back to his territory, SCylitzes, 9, 41-46, p. 240-242.
} 
so many captives that both urban and rural estates got filled with slaves ${ }^{57}$. In turn, Leo the Deacon observes that the citizens of Constantinople who witnessed the triumph were amazed by the multitude of Arab prisoners ${ }^{58}$. Sometimes, however, the status of the captives was far more important than their number. This was true of the triumph of $956 \mathrm{AD}$, for example. That year, Sayf al-Dawla launched another campaign, which proved too difficult to repel by the commanders of the Empire. The Byzantines were desperate for any success, so when Abu'l-Asha'ir (nephew of Sayf al-Dawla) was captured during Leo Phocas's raid on Aleppo, a unique manifestation of victory took place in Constantinople ${ }^{59}$. According to John Scylitzes, an exquisite triumph was held, during which Leo Phocas put his foot on the neck of the emir's nephew ${ }^{60}$. Considering the military account of 956 AD, Abu'lAsha'ir turned out to be a prisoner of great importance and value ${ }^{61}$. Curiously, immediately after the triumph, Constantine Porphyrogennetus bestowed the captives with rich gifts and honors ${ }^{62}$. This incoherent behavior proves that the treatment of Abu'l-Asha'ir during the triumph was a carefully calculated, instrumental action. Clearly, Constantine did not share the prejudices of his grandfather Basil the Macedonian.

Even though the triumph was a distinctly Byzantine ceremony, this does not mean that the Arabs would never parade their prisoners in case of a notable victory over the Christians. Although the relevant written material is far scarcer, there is at least one account referring to a triumph-like parade being held in the emirate of Aleppo. As John Scylitzes informs us, one of the sons of then Domestic of the Schools Constantine Phocas was captured by Sayf al-Dawla during the battle of Marash in $953 \mathrm{AD}^{63}$. The Byzantine chronicler mentions that the young strategos of the Theme of Seleucia was later paraded in Aleppo, following the successful Arab campaign.

The above-mentioned examples prove that whenever an important prisoner was captured, it was high priority for the commander to deliver him safely to the capital of the Empire, regardless of the campaign's prime objectives. Such a captive might have been a burden for the army at times; from the strategic perspective, however, he was of great value.

\footnotetext{
${ }^{57}$ SCylitzes, 4, 52-57, p. 250.

${ }^{58}$ Leo the Deacon speaks of myriads of Hagarens (i.e. Arabs), Leo the Deacon (Hase), II, 5; Leo THE DeACon (trans.), p. 76.

${ }^{59}$ YAHYA, p. 773.

${ }^{60}$ SCYLitZes, 9, 18-20, p. 241.

${ }^{61}$ Y. Friedman, The Nusayri-'Alawis. An Introduction to the Religion, History, and Identity of the Leading Minority in Syria, Leiden 2010 [= IHC, 77], p. 31.

${ }^{62}$ Scylitzes, 9, 21-24, p. 241.

${ }^{63}$ SCYLITZES, 9, 24-27, p. 241.
} 


\section{Prisoners of war as a source of wealth - virtual profit and real threat?}

Needless to say, prisoners meant potential financial gains for both sides of the conflict. The opportunity of capturing slaves, who could subsequently be sold or exchanged for ransom, was one of two motivations for the Arabs to raid Byzantine frontier territories (the second reason was the prospect of capturing skilled craftsmen). Surprisingly, however, taking captives during the campaign also offered many benefits for the Byzantine generals. According to Leo the Wise, should the campaign prolong too much, commanders should consider buying back prisoners from their soldiers ${ }^{64}$. At first glimpse, this makes little sense. However, one should remember that before the captives who were divided between the soldiers participating in the campaign could be sold for money, both the owners and prisoners had to survive long enough to return from war ${ }^{65}$. Thus, instead, the commander could buy back the captives from the army - which was a win-win situation for all, except for the captured. The soldiers received money and were no longer districted from fighting, while the generals got motivated soldiers. This practice was especially important in times when a soldier's pay would not always arrive on time. As correctly remarked by Timothy Dawson, it was during the reign of Constantine Porphyrogennetus that the army rebelled due to delays in pay ${ }^{66}$. As we know, after the rebellion was quelled, a decree was issued stipulating that a soldier's pay should be distributed every four years ${ }^{67}$. However, it is no secret that even at that time, delays were not an infrequent issue. Thus, even after the above regulation, soldiers would still risk their lives for a number of years before receiving any remuneration. Thus, it is clear that capturing prisoners during a campaign was an important, if not crucial, motivation for the soldiers of the Empire.

Still, one should bear in mind that the above-mentioned agenda could sometimes in fact put the whole army in peril: undisciplined soldiers who focused more on pillaging and taking prisoners than on the battle itself made for an easy target. Such a situation took place during Nicephorus II Phocas's conquest of Crete between 960-961 AD. As we learn from Leo the Deacon, the future emperor sent some troops under the command of Nicephorus Pastilas, the strategos of the Theme of Thrakesion, with the task of scouting the area. The author of the source stresses that Nicephorus Phocas warned his officer to stay cautious and not to relax the discipline ${ }^{68}$. However, the fertile rural territory, and (probably) the prospect of looting,

\footnotetext{
${ }^{64}$ The Taktika of Leo VI, XVI, 8, 41-47, trans. et ed. G. Dennis, Washington 2010 [= CFHB.SW] (cetera: Tactica), p. 385.

${ }^{65}$ Leo also teaches commanders that taking captives and pillaging is desirable in case the campaign continues for a longer time, Tactica, XVI, 4-5, p. 383-385.

${ }^{66}$ T. Dawson, Byzantine Infantryman - Eastern Roman Empire c. 900-1204, Oxford 2007, p. 41-42; IDEM, Byzantine Cavalryman c. 900-1204, Oxford 2009, p. 20.

${ }^{67}$ Constantini Porphyrogeniti imperatoris De cerimoniis aulae byzantinae libri duo, II, 44, ed. J.J. ReIsKE, Bonn 1830 [= CSHB, 1] (cetera: De Cerimoniis), p. 493-494.

${ }^{68}$ Leo the Deacon (Hase), I, 3; Leo the Deacon (trans.), p. 63.
} 
was apparently a temptation that the general could not resist. As a result, the troops fell into an Arab ambush and everyone, including Pastilas, perished in the ensuing battle.

Thus, generals knew very well that the desire to take prisoners was a doubleedged sword and that it could affect the whole campaign. Leo the Wise instructs his generals that while plundering enemy territory is a sound move, it should be carried out with caution and according to a strict order ${ }^{69}$. What is more, the officers' duty was not only to select the soldiers for the expedition, but also to prevent unwanted volunteers for joining the looting party $^{70}$. This regulation also applied to taking prisoners from among the defeated army in case the battle was won. The author of the Praecepta Militaria stresses that it is unacceptable for soldiers to focus on dividing the booty or capturing prisoners before such a command is given ${ }^{71}$. In case an enemy line was broken, soldiers were forbidden to engage in pursuit, except for those who were entrusted with such a mission ${ }^{72}$.

This, however, leads to another question: if the prisoners were already divided by the time when the triumph in the capital was held, when did the division of the booty usually take place? On the basis of Constantine Porphyrogennetus's account of emperor Theophilus's triumph, Abdelaziz Ramadan argues that the division of booty occurred after the campaign, i.e. just before the triumphal parade in the capita $^{73}$. However, there are also reasons to assume that it might well have taken place before the return to Constantinople. According to Leo the Deacon's description of Leo's victory over Sayf al-Dawla in $960 \mathrm{AD}$, the general divided the goods and captives right after the battle ${ }^{74}$. It seems undisputable that Nicephorus Phocas did the same thing after taking Chandax, i.e. the capital of the Arab emirate of Crete ${ }^{75}$. The loot was also divided among the Byzantine soldiers immediately after the capture of Mopsuestia in $965 \mathrm{AD}$ and of Antioch in $969 \mathrm{AD}^{76}$. Nevertheless, these examples do not mean that a general could not decide otherwise; it seems reasonable to suppose that the commander would have the final say in this matter ${ }^{77}$. The main criteria were probably the tactical situation and the morale among the soldiers.

\footnotetext{
${ }^{69}$ Tactica, XVII, 36, 191-197, p. 405-407.

${ }^{70}$ Tactica, XVII, 53, 300-304, p. 413 - those who transgressed this regulation were punished in accordance with military law.

${ }^{71}$ Praecepta Militaria, II, 7, 68-76, [in:] E. McGeen, Sowing the Dragon's Teeth. Byzantine Warfare in the Tenth Century, Washington 1995 [= DOS, 33] (cetera: Praecepta Militaria), p. 27.

${ }^{72}$ Praecepta Militaria, IV, 14, 57-64, p. 49.

${ }^{73}$ A. Ramadan, The Treatment..., p. 162-163; Three Treatises, p. 163.

${ }^{74}$ Leo the Deacon (Hase), II, 4; Leo the Deacon (trans.), p. 75.

${ }^{75}$ Leo the Deacon (Hase), II, 8; Leo the Deacon (trans.), p. 79-80.

${ }^{76}$ Leo the Deacon (Hase), III, 11; V, 4, col. 779-780; Leo the Deacon (trans.), p. 102; V, 4, p. 134.

${ }^{77}$ Whether or not prisoners would be taken also depended on the commander's decision, Tactica, XVI, 7, 39-40, p. 385.
} 
While reconstructing the process of the division of loot in the $10^{\text {th }}$ century army is a useful enterprise, one can gain even better insight into the motivations of the Byzantine soldiers by determining how much a prisoner was worth during the period in question. In order to do so, we must first address the issue of the average pay of the soldiers at the time. As argued by Cecile Morrisson and Jean-Claude Cheynet, it would have been comparable with the monthly wage of an unskilled worker, amounting to one gold nomisma ${ }^{78}$. Of course, it is clear that the people who received this pay were simple rank-and-file soldiers of the theme armies ${ }^{79}$. This estimation also receives some support from the written sources, since the Arab chronicler Ibn Khurdadbeh reports that a veteran soldier's annual pay was 12-18 gold dinars ${ }^{80}$. This amount of money would easily suffice as a basic livelihood for the whole family, on condition that there was no famine or disease and that the city was not besieged ${ }^{81}$. C. Morrisson and J.-C. Cheynet argue that the pay of soldiers from more prestigious formations, such as the tagmata, was at least twice as high ${ }^{82}$. Officers earned 25-30 nomisma on average; however, high-ranking officers enjoyed real luxury, since their pay was counted in pounds of gold ${ }^{83}$. According to Ibn Khurdadbeh, the lowest pay of a strategos was 6 pounds of gold $^{84}$ (approximately 432 nomisma ${ }^{85}$ ).

The written sources also offer some information about the ransom for different categories of captives. The amount of money paid for a prisoner's freedom varied greatly, depending primarily on his provenance ${ }^{86}$. C. Morrisson and J.-C. Cheynet provide strong evidence to assume that the highest ransom was paid for state officials, Church notables, and of course nobles taken captive during military

\footnotetext{
${ }^{78}$ C. Morrisson, J.-C. Cheynet, Prices and Wages in the Byzantine World, [in:] The Economic History of Byzantium. From the Seventh through the Fifteenth Century, ed. A.E. LaIou, Washington 2002, p. 872.

${ }^{79}$ S. Blondal, The Varangians of Byzantium. An Aspect of Byzantine Military History, trans. B.S. BENEDIKZ, Cambridge 1978, p. 25.

${ }^{80}$ Ibn KhordÂdhbeh, Kitab al-Masalik wa'l-Mamalik, ed. M.J. De Goeje, Lugduni Batavorum 1889 [= BGA, 6] (cetera: IbN KhuRdAdBeh), p. 84. It is worth mentioning that by doing so, the Arab chronicler sees no difference in the value of gold nomisma and gold dinar. The fact that Arab prisoners invited to Eastern ceremonies at the Byzantine court received 3 nomismata shows that the gift was a valuable one, L. Simeonova, In the Depths..., p. 89.

${ }^{81}$ C. Morrisson, J.-C. Cheynet, Prices..., p. 873. At the time of peace, $1 \mathrm{~kg}$ of bread was worth approximately $3-8$ folleis.

${ }^{82}$ Ibidem, p. 872.

${ }^{83}$ Depending on the rank and region of service, the amount in question was between 5 and 40 litrai, De cerimoniis, II, 50, p. 696-697.

${ }^{84}$ Ibn Khurdadbeh, p. 84.

${ }^{85}$ Were we to stick to the nominal amount, this would be equivalent to 5184 silver milaresia and 124416 folleis, the most common currency in everyday life.

${ }^{86}$ For instance, Anthony CUTLER states that the regular price for a prisoner during the reign of Leo VI was 107 dinars. However, one should assume that this sum referred to captives of noble birth (Gifts and Gift Exchange as Aspects of the Byzantine, Arab, and Related Economies, DOP 55, 2001, p. 252).
} 
operations ${ }^{87}$. As regards the period in question, the above-mentioned scholars give two examples. In the first case, a ransom of 5000 dinars was accepted in return for the freedom of the governor of Byzantine Apulia in $925 \mathrm{AD}^{88}$. In the second example, the sum was even higher: in order to set free a member of the Dalassenus family in $998 \mathrm{AD}$, it was necessary to pay no less than 6000 dinars $^{89}$. Of course, one should emphasize that it is difficult to decide what currency is in fact hidden behind the dinar. It is possible that the authors of the sources referred to standard gold coins; however, one must remember that the dinar and the nomisma were in fact two separate currencies. The former was of Arab provenance and amounted to approximately $4.25 \mathrm{~g}$ of gold ${ }^{90}$, while the latter was slightly heavier, theoretically reaching $4.5 \mathrm{~g}$ of pure gold ${ }^{91}$. If the authors meant Arab dinars, then the amounts expressed in nomismata would be 4722 and 5666 gold pieces, respectively. However, we should add that a few different versions of both currencies existed during the period in question. Thus, the sums are of a purely tentative character ${ }^{92}$.

Be that as it may, the above sums were exorbitantly high, out of reach for ordinary citizens of Byzantium or the Caliphate. Accordingly, it is improbable that commanders would allow rank-and-file soldiers to keep such precious prisoners for themselves. Also, one should bear in mind that the division of the booty often took place directly after the battle, with $1 / 6$ to $1 / 5$ of the goods (depending on the source) being allocated to the imperial treasury ${ }^{93}$. Still, it is perfectly possible that even an ordinary soldier could take a prisoner from the enemy army in order to sell him to his commander or at a slave market after the campaign finished. How profitable was this? According to C. Morrisson and J.-C. Cheynet, the approximate value of a prisoner of war (without any noteworthy status) oscillated around

\footnotetext{
${ }^{87}$ C. Morrisson, J.-C. Cheynet, Prices..., p. 845-846.

${ }^{88}$ Ibidem, p. 845.

${ }^{89}$ Ibidem.

${ }^{90} \mathrm{~J}$. Porteous, Coins in History. A Survey of Coinage from the Reform of Diocletian to the Latin Monetary Union, London 1969, p. 14-33.

${ }^{91}$ P. Grierson, Nomisma, [in:] ODB, vol. III, p. 1490; IDEM, Solidus, [in:] ODB, vol. III, p. 1924.

${ }^{92}$ Inconsistencies of this kind were frequently utilized by Byzantine emperors, who were always in need of money. Thus, it was a frequent practice to replace one currency with another, taking advantage of the ratio. A good example of such politics is the reform implemented by Nicephorus II Phocas, who demanded taxes in a heavier nomisma (histamenon), while he paid all expenses in a lighter one (tetarteron), P. GRIERson, Tetarteron, [in:] ODB, vol. III, p. 2026-2027.

${ }^{93}$ The sources disagree on this matter. According to the author of the Ecloga, one-sixth was reserved for the imperial treasury (Ecloga. Das Gesetzbuch Leons III. und Konstantinos' V., ed. L. Burgmann, Frankfurt 1983 [= FBR, 10], p. 245). The author of the Sylloge Tacticorum gives the same information (A Tenth-Century Byzantine Military Manual. The Sylloge Tacticorum, trans. G. Chatzelis, J. HaRRIs, London 2017 [= BBOS] (cetera: Sylloge Tacticorum), p. 84-85). Interestingly enough, however, Leo VI demands in his Tactica no less than $1 / 5$ of the booty (Tactica, XX, 192, 976-981, p. 604-605). Considering that the Sylloge Tacticorum is a younger source than the Tactica, one can suspect that the regulation changed over time.
} 
10-15 nomismata ${ }^{94}$. This means that in the case of a victorious battle, at least some soldiers - those fortunate enough to capture an enemy - could become richer by almost a year's pay.

Ransom was sometimes payed not only for individuals, but also for whole groups of prisoners. Arnold Toynbee and Clément Huart point out that the Arabs paid 80000 dinars for 230 captives held by the Byzantines in $946 \mathrm{AD}^{95}$. This would put the average ransom at around 347 gold dinars (or 327 nomismata) per prisoner. Almost twenty years later, in $966 \mathrm{AD}$, Sayf al-Dawla pledged to buy back 3000 of his soldiers from Nicephorus II Phocas for 270 dinars (255 nomisma) each ${ }^{96}$. Regardless of the exact sum, it is clear that in both cases the prisoners in question must have been people of certain prominence, since the ransom greatly exceeded the average sum for rank-and-file soldiers. What is more, there is some proof that there were indeed certain notable individuals among the captives, such as Abu Firas, who regained freedom after at least six years ${ }^{97}$.

Summing up, the prospect of capturing a prisoner was a considerable temptation for the Byzantine soldiers, especially in the light of the problems with regular payment. Besides, capturing prisoners of high social status allowed officers and generals to enrich themselves even more. Taking prisoners after victorious battles was also profitable for the state, since part of the loot was transferred to the imperial treasury automatically. What is more, the prisoners could later be sold back to the Caliphate for a substantial amount of gold. However, the prospect of financial gain was also a threat to the discipline during the campaign: there was the risk that soldiers would pay more attention to taking captives than to fighting the battle. In short, greed could bring about the defeat of a whole army. This is why the authors of military manuals drew such attention to the issue of discipline during and after the battle. The most common way to ensure order among soldiers was to select groups of men responsible for pursuit and taking captives in case the enemy lines were broken; such soldiers were appointed in advance ${ }^{98}$.

\section{Exchanging prisoners - an asset during negotiations?}

Enemy soldiers or civilians captured by the Byzantines were also an asset during the prospective peace negotiations. Leo the Wise urges his commanders not to kill prisoners until the end of the campaign, since they may be utilized to free citizens of

\footnotetext{
${ }_{94}$ This estimation excludes clergy, for the above-mentioned reasons, C. Morrisson, J.-C. Cheynet, Prices..., p. 846.

${ }^{95}$ A. Toynbee, Constantine Porphyrogenitus and His World, London-New York 1973, p. 392-393;

C. Huart, Lamas-Șū, [in:] The Encyclopedia of Islam. New Edition, vol. V, Leiden-New York 1986, p. 647.

${ }^{96}$ Yahya, p. 804; C. Morrisson, J.-C. Cheynet, Prices..., p. 846.

${ }^{97}$ During that time, the Arab poet probably met the emperor Nicephorus II Phocas, J. SyPIAŃski, Arabo-Byzantine..., p. 467.

${ }^{98}$ Praecepta Militaria, IV, 14, 158-166, p. 47-49.
} 
the Empire from slavery or even to capture an important fortress ${ }^{99}$. The authors of the sources confirm that at earlier stages of the Arab-Byzantine conflict, such exchanges were resolved between the emperor and the caliph; with time, however, the Byzantine authorities started to negotiate on this matter directly with the bordering emirates ${ }^{100}$. A. Ramadan points out that a traditional place of exchanging prisoners during the $10^{\text {th }}$ century was Tarsus ${ }^{101}$. In case the enemy was unwilling to conclude the transaction, Leo would let his generals decide what to do with the prisoners ${ }^{102}$. Thus, as a rule, most of them were sold into slavery.

It appears that the procedure of exchanging prisoners was applied frequently in the Arab-Byzantine conflict of the $10^{\text {th }}$ century ${ }^{103}$. Arab chronicler al-Tabari informs us that in $902 \mathrm{AD}$ Leo the Wise sent an emissary to the caliph in order to arrange a treaty involving such a trade-off ${ }^{104}$. The agreement was probably not fulfilled in its entirety due to the emperor's suspicions concerning the loyalty of one of the generals (namely Andronicus Ducas) ${ }^{105}$. Thus, the exchange of $905 \mathrm{AD}$ was discontinued, and only part of the prisoners was set free ${ }^{106}$. As Bar Hebraeus informs us, the eunuch Basil had to travel to the caliph's court once again in $906 / 907 \mathrm{AD}$ in order to seek another agreement with the Arabs ${ }^{107}$. Eventually, the deal was reached in $908 \mathrm{AD}$, and according to the sources 3000 people were freed on both sides ${ }^{108}$.

Sometimes, however, the exchange of prisoners was only a part of a more complex treaty. One such agreement was signed on behalf of empress and regent Zoe with the emir of Tarsus in 917 AD. The treaty was crucial for the Empire, since the Byzantines were determined to resolve their problems with Bulgarian Tsar Simeon once and for all. Thus, apart from the non-aggression pact, an exchange of prisoners was agreed to ${ }^{109}$. Describing the above events, Bar Hebraeus mentions one more

${ }^{99}$ Tactica, XVI, 9, 50-54, p. 384-385. This was something of a novelty, since in the previous century Arabs unwilling to convert were tortured and executed, L. Simeonova, In the Depths..., p. 77.

${ }^{100}$ On Byzantine and Arab envoys see M.T. Mansouri, Byzantium and the Arabs from the VII to ${ }^{\text {th }}{ }^{\text {th }}$ Century, MW/MS 20, 2010, p. 63-65.

${ }^{101}$ A. Ramadan, The Treatment..., p. 161.

102 Tactica, XVI, 9, 54-55, p. 386-387.

${ }^{103}$ K. Durak, Traffic..., p. 146. This applies to the earlier period as well - Cutler (Gifts..., p. 252) points out that the Byzantines were ready to set free 200 Arab prisoners and pay 12000 nomismata only to recover the lost Mandylion. On another note, as remarked by Simeonova, the mass scale and high frequency of those exchanges contributed to a more humane treatment of the prisoners, L. Simeonova, In the Depths..., p. 76.

${ }^{104}$ The History of al-Tabari, vol. XXXVIII, The Return of the Caliphate to Baghdad, y. 902, trans. F. Rosenthal, Albany 1985 [= BPe] (cetera: Al-Tabari), p. 133.

${ }^{105}$ W. Treadgold, A History..., p. 468.

${ }^{106}$ AL-TABari, y. 905, p. 153. 1200 Muslims were freed as a result.

${ }^{107}$ Al-Tabari, y. 906, p. 181; Bar Hebraeus, X, p. 154-155.

${ }^{108}$ Al-Tabari, y. 908, p. 185; Bar Hebraeus, X, p. 155. According to the author, 3000 people were exchanged.

${ }^{109}$ Leo Grammaticus, p. 81. 
interesting detail: that year, according to the chronicler, the emissaries of caliph al-Muktadir arrived in Constantinople carrying a large sum of money (170 000 gold dinars $)^{110}$. Their aim was to ransom more Arab prisoners, since Byzantines held far more captives than the Muslim rulers did. This account gives us some reasons to assume that the Byzantine administration avoided selling all their captives, saving some of them for a potential future exchange ${ }^{111}$. Indeed, such opportunities appeared quite regularly: three major treaties were signed before $950 \mathrm{AD}$, not taking into account the numerous minor, local agreements at the frontier of the Empire. C. Huart and A. Toynbee point out that a large exchange involving 4000 people took place in $925 \mathrm{AD}^{112}$. Moreover a $938 \mathrm{AD}$ treaty is mentioned by Yahya of Antioch ${ }^{113}$, while yet another exchange took place eight years later. The author of Theophanes Continuatus notes that 2500 people were freed in 946; the Arabs also ransomed the remaining group of 230 captives for a sum of 80000 dinars $^{114}$. This is also the last major treaty until $966 \mathrm{AD}$, when Sayf al-Dawla petitioned Nicephorus II Phocas for an agreement by which 3000 Arab soldiers regained freedom ${ }^{115}$. It is also worth mentioning that the very organization of an exchange of prisoners presumably included costly preparations ${ }^{116}$.

Although these exchanges involved large groups of prisoners, it is clear that only a small part of the captured soldiers were lucky enough to be eligible for the procedure ${ }^{117}$ : as stressed by A. Ramadan, most of them became slaves ${ }^{118}$. The scale of the practice must have been considerable, given that it attracted the attention of the emperor himself: as the number of slaves in Byzantium increased, John Tzimiskes issued a law regulating slave trade in the territory of the whole empire. Eric McGeer observes that the novel was issued between 972-975 AD, when Byzantium finally got the upper hand in the conflict with the Arabs and completed the conquest of northern Syria ${ }^{119}$. The influx of slaves was substantial, which

\footnotetext{
${ }^{110}$ Bar Hebraeus, X, p. 156-157.

${ }^{111}$ It seems that an organized jail system was created for the Arab prisoners. One of the prisons was meant for Tarsians. High-status captives were held separately, while rank-and-file soldiers were imprisoned in provincial thematic centers, L. Simeonova, In the Depths..., p. 90-91; K. Durak, Traffic..., p. 145.

112 A. Toynbee, Constantine..., p. 392-393; C. Huart, Lamas-Șü..., p. 647.

${ }^{113}$ According to Yahya the exchange took place in 938 AD, YAнYA, p. 710.

114 Theophanes Continuatus, VI, 9, 1-12, p. 442-443.

${ }^{115}$ YAHYA, p. 804.

116 These involved valuable gifts given to the rulers, A. Cutler, Gifts..., p. 264-269. One should bear in mind that at least since the time of Leo VI, the Arabs occupied a high position within the Byzantine diplomatic protocol, L. Simeonova, In the Depths..., p. 78. Consequently, any prisoner exchange or diplomatic visit was an opportunity to show Arab or Byzantine superiority over the enemy, J. Sypiański, Arabo-Byzantine..., p. 465-466.

${ }^{117}$ Among those who were not likely to be sold into slavery directly after the campaign were qualified workers, artists, and craftsmen, A. Cutler, Gifts..., p. 255.

${ }_{118}$ A. Ramadan, The Treatment..., p. 162-166; K. Durak, Traffic..., p. 144.

${ }^{119}$ E. McGeER, Sowing..., p. 368.
} 
required clear fiscal regulations. According to the new law, the trade between a soldier possessing a prisoner and his commander was exempt from taxation. However, curiously enough, if the owner decided to sell his captive to someone unrelated to the campaign - e.g. at the marketplace in Constantinople - then the transaction was taxed ${ }^{120}$. Thus, the regulations in question evidently favored situations in which commanders bought back prisoners from their soldiers, possibly for a price lower than the free market one. In any case, the law proves that slave trade became an important issue towards the end of the period in question and required the emperor's intervention. The sources also corroborate the claim that Byzantine generals were not only willing to take prisoners, but it was sometimes also the main goal of the campaign.

\section{Prominent prisoners - too precious to set them free?}

The examples adduced above show that some prisoners, especially those of noble descent and related to the powerful elite, were perceived as particularly valuable, so that their captors were determined to keep them alive. However, this does not mean that they could always count on regaining their freedom. The abovementioned Abu'l-Asha'ir, although living in luxury and treated with honor, never returned to his country ${ }^{121}$. A similar fate befell many Byzantine nobles unlucky enough to be captured by the Arabs. One example is Constantine Phocas, the son of Bardas (then Domestic of the Schools), taken prisoner by Sayf al-Dawla during the battle of Marash. The Byzantine chronicler John Scylitzes claims that the domestic's son was poisoned by the emir of Aleppo after refusing to convert to Islam ${ }^{122}$. In fact, Constantine's death brought fatal consequences to both sides of the conflict: as we are told by Scylitzes, Bardas ordered to slaughter all Arab prisoners in his possession, including the relatives of Sayf al-Dawla ${ }^{123}$. What is more, no prisoner exchanges took place between 954-966 AD. These two facts alone prove that the death of the domestic's son was a major scandal. Interestingly, while Byzantine chroniclers blame the emir of Aleppo for Constantine's death, Arab chroniclers - such as Ibn Shaddād - portray the relevant events differently ${ }^{124}$. According to their tradition it was the Byzantines who arranged the poisoning

\footnotetext{
${ }^{120}$ Novella of the Emperor John Concerning the Tax on Slaves Taken in War, [in:] E. McGeER, Sowing..., p. 368.

${ }^{121}$ Yahya of Antioch states explicitly that he died in captivity, YAнYA, p. 773.

${ }^{122}$ SCylitzes, 9, 24-27, p. 241.

${ }^{123}$ SCylitzes, 9, 27-29, p. 241.

${ }^{124}$ Alexander A. VAsiliev (Byzance..., p. 196) argues that Constantine and Sayf al-Dawla were in good relations when the former lived in captivity. Bardas is said to have offered 800000 dinars and $3000 \mathrm{Arab}$ prisoners in return for freeing his son, but the offer was rejected. As a proof for the abovementioned relationship, Vasiliev refers to the account of Ibn Shaddad (Ms Vatican, 730, Fo 215, II, 2, post: A.A. Vasiliev, Byzance..., p. 196).
} 
of the young general after Sayf al-Dawla rejected the offer of ransom issued by Bardas $^{125}$. Yahya of Antioch claims that Constantine was treated by the emir with respect, and was buried with honors by the local Christian community of Alep$\mathrm{po}^{126}$. One must admit that this latter interpretation of the events is viewed as more plausible in modern scholarship. Aleksandr A. Vasiliev points out that Sayf al-Dawla acted in accordance with a long-standing Arab tradition, caring for his prisoner and doing everything he could to save his life. When this was to no avail, he wrote a letter to Bardas explaining the circumstances of his son's death ${ }^{127}$. Similarly, J.-C. Cheynet states that it is improbable that the emir of Aleppo was responsible for Constantine's death ${ }^{128}$ : if he had been the one who had the young general poisoned, he would not have cared to explain himself to his father. Although the mystery remains unsolved, it cannot be doubted that the incident greatly affected the already tense relations between the Arabs and the Byzantines ${ }^{129}$.

Sometimes, however, one comes across stories with a happy ending. Such was the case of Abu Firas, a relative of Sayf al-Dawla ${ }^{130}$. The nobleman in question was not only the governor of the strategically important cities of Manbij and Harran, but also one of the most eminent Arab poets of his time ${ }^{131}$. According to various accounts, he was captured sometime between 959-962 AD, certainly during the rule of Romanus $\mathrm{II}^{132}$. His captor, Theodore Parsacutenus, did his best to exchange him for his own father and brother, who had remained in captivity since 954 AD. Curiously enough, however, Sayf al-Dawla would rather leave his relative in a Byzantine prison than release those two generals ${ }^{133}$. Eventually, Abu Firas was released in $966 \mathrm{AD}$ as a result of the prisoner exchange arranged by the emir of Aleppo and Nicephorus II Phocas ${ }^{134}$. Although we may only speculate why Sayf al-Dawla waited so long, it is likely that letting go of certain prisoners was simply too risky ${ }^{135}$. Such valuable captives were treated at least in an acceptable way and

${ }^{125}$ A.A. VAsiliev, Byzance..., p. 196. Koray Durak reconstructs the same sequence of events, though without mentioning Bardas Phocas's name directly, K. Durak, Traffic..., p. 148.

${ }^{126}$ YAHYA, p. 771.

127 A.A. VAsiliev, Byzance..., p. 351.

${ }^{128}$ John Skylitzes, A Synopsis..., p. 233, an. 39.

${ }^{129}$ The case of Constantine's death is indeed a mysterious one. It seems that, as a matter of fact, the final result was detrimental to all of the parties involved: Bardas lost his beloved son, while Sayf must have been aware that killing the domestic's son would have been tantamount to putting his own relatives in Byzantine captivity in tremendous risk.

${ }^{130}$ H.A.R. GibB, Abū Firās, [in:] The Encyclopedia..., vol. I, p. 119-120.

${ }^{131}$ S.E.H.A. Niaki, H.S. ChafjIRI, The Common Themes of Prison Poetry in the Poems by Abu-Firas Al-Hamdani and Mas'od Sa'd Salman, JAEBS 5, 2015, p. 286-287.

${ }^{132}$ Vaticani arabi, 730, Fo 246, II, 3 (post: A.A. VAsiliev, Byzance..., p. 197). Abu Firas was captured around 959 AD, A.A. VAsiliev, Byzance..., p. 197.

${ }^{133}$ PMZ II, vol. VI, p. 368-369 (s.v. Theodoros Parsakutenos, \#27758).

${ }^{134}$ W. Treadgold, A History ..., p. 501.

${ }^{135}$ In the case of such prisoners, it is likely that the emir knew their military talents and was thus reluctant to release them. As far as Constantine Bardas is concerned, Sayf may have hoped for achieving certain non-financial benefits, such as e.g. giving up a strategically important fortress. 
often had access to their captors (this was the case with Constantine Phocas). Besides, Abu Firas was visited at least once by Nicephorus II Phocas - who, we may note, insulted the poet claiming that the Arabs are meant to write but not to fight ${ }^{136}$.

The above examples prove that, in some cases, it was more cost-effective to keep notable captives in prison than to exchange them, even if this meant spending a substantial amount of money ${ }^{137}$. Sometimes, the reason behind the refusal was the military skill of a given prisoner.

\section{Kill them all! - Revenge, necessity or calculation?}

Leo the Wise mentions in his Tactica that under certain circumstances the campaigning army should not take any booty (i.e. also no prisoners) ${ }^{138}$. Thus, on some occasions, generals were not interested in keeping the captives alive. One of the reasons why both the Arabs and the Byzantines would slaughter their prisoners was vengeance. As stressed by A. Ramadan, the practice emerged from the fact that the conflict between the Eastern Christians and the Muslims in the $9^{\text {th }}-10^{\text {th }}$ centuries was an intense one, with a strong ideological component ${ }^{139}$. Thus, it is no secret that both sides committed acts of cruelty. One of the sources that shed some light on the atmosphere of the war is the chronicle of Ibn Khurdadbeh. The historian states that the Byzantine nobles (i.e. the generals called patrikioi) not only fought the Muslims with the sword, but also tortured the prisoners by burning them alive ${ }^{140}$. In some cases, revenge was a personal matter - as in the case of Bardas Phocas, who ordered the execution of all Arab prisoners upon hearing of his son's death in captivity ${ }^{141}$. This act of vengeance was certainly quite dramatic, since it involved Sayf al-Dawla's relatives, who had been in Byzantine captivity for some time already.

A. Ramadan remarks that an equally dramatic event took place after the unsuccessful plot against the court of Aleppo instigated by the Byzantines in $957 \mathrm{AD}$. In retaliation for the conspiracy, Sayf al-Dawla executed 400 Byzantine host-

\footnotetext{
${ }^{136}$ Dìwān al-Amìr Abì Firās al-Hạmdānī, ed. M. AL-TunjI, Damascus 1987, p. 34. It is striking that, during the period in question, the Arabs in fact showed greater interest in classical Greek culture than the Byzantines, J. Sy piański, Arabo-Byzantine..., p. 470.

${ }^{137}$ Sometimes, these valuable prisoners could be utilized for achieving diplomatic goals. Although the example comes from later period, it is worth noting that Nur ad-Din decided to set free some 1000 crusader prisoners and their leaders in order to avoid a joint Byzantine-Crusader campaign, A. Cutler, Gifts..., p. 259.

${ }^{138}$ Tactica, XVI, 7, 39-40, p. 384-385.

${ }^{139}$ A. Ramadan, The Treatment..., p. 157.

${ }^{140}$ Ibn KhuRdadbeh, p. 109. Specifically, the Arab chronicler mentions burning the prisoners with fire while they were tied to iron bars. Also, while patrikios is clearly a court dignity, Ibn Khurdadbeh must have meant military commanders holding this rank.

${ }^{141}$ Scylitzes, 9, 27-29, p. 241. However, one must admit that, starting with the reign of Leo VI, the Byzantines showed moderate leniency towards the Arabs, L. Simeonova, In the Depths..., p. 79-80.
} 
ages $^{142}$. W. Treadgold suggests that this decision might have been the result of a spontaneous impulse ${ }^{143}$. Nicephorus II Phocas, too, slaughtered Arab prisoners for personal reasons: as we learn from Bar Hebraeus, after the emperor's nephew was killed during the siege of Antioch between 962-963 AD, Nicephorus ordered the execution of 1200 Arab captives as an act of vengeance ${ }^{144}$. Similarly, A. Ramadan points out that both the Arabs and the Byzantines massacred prisoners during the siege of Tarsus in $965 \mathrm{AD}^{145}$.

However, there were also situations in which the generals executed the captives in spite of earlier plans to the contrary. There are at least two examples from the period in question showing how people's lives turned from asset to burden for commanders. The first situation took place in $878 \mathrm{AD}$, during Basil the Macedonian's campaign ${ }^{146}$. Though in general successful, the operation did not result in the capture of any of the important Arab strongholds, save for Geron ${ }^{147}$. Thus, Basil had to face the prospect of withdrawal with a large enemy force behind, while his army was slowed down by prisoners taken during the campaign. Even though the emperor primarily allowed the division of spoils and captives among the soldiers, after some time he changed his mind and ordered the execution of all prisoners ${ }^{148}$. A most similar drama enfolded almost 75 years later, when Sayf al-Dawla retreated to Aleppo after a successful campaign with many notable Byzantine captives ${ }^{149}$. As we are told by John Scylitzes, the Arab army was ambushed by Leo Phocas, so that the emir had to slaughter the prisoners in order to secure a successful retreat to his territory ${ }^{150}$. J.-C. Cheynet argues that this was in fact a great loss not only for the Byzantines, but also for Sayf al-Dawla, since the 400 hostages in question were of noble descent and could have been exchanged for a substantial ransom ${ }^{151}$. Although both events were clearly dramatic, it seems that the decisions were the result of pure calculation. Leo the Wise advises his generals that if the army is surprised by the enemy during a withdrawal while carrying booty and prisoners, the commander may negotiate the terms of evacuation with the adversaries in return

\footnotetext{
${ }^{142}$ A. Ramadan, The Treatment..., p. 157.

${ }^{143}$ W. Treadgold, A History..., p. 493.

${ }^{144}$ Bar Hebraeus, X, p. 169.

${ }^{145}$ A. Ramadan, The Treatment..., p. 159.

${ }^{146}$ W. Treadgold, A History..., p. 458.

${ }^{147}$ The emperor could capture neither Samosata nor Germanicea nor Adata, Theophanes Continuatus, V, 48, 1-10, p. 280.

${ }^{148}$ Theophanes Continuatus, V, 49, 1-8, p. 283.

${ }^{149}$ A. Ramadan (The Treatment..., p. 157) wrongly connects Scylitzes's account with the battle of $956 \mathrm{AD}$ - in fact, the chronicler does not stick to linear chronology strictly. Similarly, J.-C. CHEYNET in his comment on the translation of SCylitzes, argues that the massacre took place in $950 \mathrm{AD}$, John SkyLitzes, A Synopsis..., p. 234, an. 42.

${ }^{150}$ SCyLITZES, 9, 45-46, p. 242.

${ }^{151}$ John Skylitzes, A Synopsis..., p. 234, an. 42; W. Treadgold, A History ..., p. 489.
} 
for freeing the captives ${ }^{152}$. In the case of refusal, however, the general should have the captives executed in front of the enemy army and then withdraw as best as one $\mathrm{can}^{153}$. Likewise, the anonymous author of De velitatione advises commanders who find themselves in such a situation either to kill the prisoners or to send them ahead $^{154}$. Thus, both military manuals justify executing captives in case the army is in danger.

Sometimes, however, slaughtering prisoners of war was not a necessity of the moment, but a carefully thought-out strategy. This was probably the case during John Tzimiskes's campaign of $963 \mathrm{AD}^{155}$. According to Scylitzes's account, after the elite contingent of Sayf al-Dawla was broken, the defeated soldiers sought refuge in the mountainous terrain ${ }^{156}$. Although giving up the pursuit to avoid sustaining possible casualties seemed the reasonable option, Tzimiskes nevertheless chased the Arabs until the last soldier was dead ${ }^{157}$. J.-C. Cheynet rightly asserts that the general wanted to eliminate the emir's best soldiers, thus weakening him permanently ${ }^{158}$. This was no isolated incident; as a matter of fact, the Byzantines were quite inclined toward cold calculation. Another such example is furnished by Ibn al-Athir, who tells us about the slaughtering of 400 Arab prisoners at the ArabByzantine frontier in $927 \mathrm{AD}^{159}$. Notably, this was the time when the Byzantines subjugated the Melitene Emirate for the first time (though for a short period only). In fact, Scylitzes claims that John Curcuas brought the citizens to despair, so that they had no option but to ask for a treaty ${ }^{160}$. Thus, the first defeat of the Melitene Emirate may in fact have been achieved through intimidation, which in turn was the effect of the slaughtering of the Arab captives. Instrumentalizing the death of enemy combatants was also the tactic employed by Nicephorus II Phocas during his conquest of Crete in 960-961 AD - Athina Kolia-Dermitzaki argues that the future emperor resorted to executing the prisoners during the campaign ${ }^{161}$. In Leo the Deacon's narrative, however, we only hear of beheading already dead Arab soldiers in order to display them to the besieged ${ }^{162}$.

${ }^{152}$ Tactica, IX, 49, p. 174-175.

${ }^{153}$ Tactica, IX, 50, p. 174-175.

${ }^{154}$ De velitatione, 11, 27-31, [in:] Three Byzantine Military... (cetera: De velitatione), p. 185.

${ }^{155}$ John Scylitzes mentions that it took place soon after Nicephorus II ascended the throne, SCYLITZES, 10, p. 267-268.

${ }^{156}$ SCylitzes, 10, 80-82, p. 268.

${ }^{157}$ SCylitZes, 10, 83-88, p. 268.

${ }^{158}$ John Skylitzes, A Synopsis..., p. 257, an. 32.

${ }^{159}$ IBn AL-AThir, al-Kāmil fì at-Ta’ rìkh, 315 (927), ed. M.Y. AL-DAQAQ, Beirut 1987, p. 35.

${ }^{160}$ Scylitzes, $19,61-65$, p. 224-225.

${ }^{161}$ A. Kolia-Dermitzaki, Some Remarks on the Fate of Prisoners of War in Byzantium $\left(9^{\text {th }}-10^{\text {th }}\right.$ Centuries), [in:] La liberazione dei 'captivi' tra cristianità e islam. Oltre La Crociata e il Ğihād. Tolleranza e servizio umanitario. Atti del Congresso interdisciplinare di studi storici, ed. G. GIPOLlone, Città del Vaticano 2000 [= CAV, 46], p. 586.

${ }^{162}$ Leo the Deacon (Hase), I, 7; Leo the Deacon (trans.), p. 67. 
In any case, it is evident that there were situations in which Byzantine generals and Arab leaders alike killed their prisoners. As a rule, it happened out of revenge, due to an urgent necessity, or as part of a pre-planned strategy. Depending on the situation, the prisoners' life could be used a tool for punishing the enemy, saving one's own army, or exerting pressure on a besieged foe.

\section{Prisoners as a burden for the campaigning army}

It is clear that both notable and rank-and-file captives were a logistic challenge for the campaigning army. The prisoners had to be guarded, consumed part of the available food supplies, and slowed down the captors' march. As we may conclude from the written sources, both Byzantine and Arab armies were exposed to unexpected attacks and ambushes not only during the campaign itself, but also during the return home ${ }^{163}$. In the historical period under discussion, the Byzantines in fact favored engaging enemy armies when they were already on their way back $^{164}$. Such a tactic would have been unacceptable for the anonymous author of the Treaty on Strategy from the $6^{\text {th }}$ century ${ }^{165}$ : according to this document, a general should see to the safety of the local population before undertaking any action against the enemy ${ }^{166}$. However, the above tactic would not have brought any good against the mobile raiding parties of the Arab emirates, typically employing hitand-run scenarios. The change in the Byzantine tactics was connected with the characteristics of the border conflict, which, in this case, involved marches across a difficult, mountainous terrain ${ }^{167}$. Accordingly, overcoming the local defenses and taking booty was only part of the task of the raiding Hamdanid armies. The second phase of the operation involved the return to the emirate of Aleppo, and this was in fact the crucial and often the riskiest stage ${ }^{168}$. The presence of the captives made the aggressor's army vulnerable to attack, which the Byzantines knew perfectly well. This is precisely the reason why Leo the Wise advises his generals to attack the Arabs while they are on their return journey through the Taurus mountains ${ }^{169}$. The author of De velitatione goes even further: according to the anonymous general, one should allow the Arabs to pillage and plunder until the raiding party decides

\footnotetext{
${ }^{163}$ One should stress that both sides used the same routes across the Cilician frontier, which made a surprise attack even more probable, K. DuRAK, Traffic..., p. 143-144.

${ }^{164}$ Generally speaking, the Byzantines were known for employing stratagems in order to wear down their opponents, E. McGeer, Sowing..., p. 254-255.

${ }^{165}$ De Re Strategica, 5, p. 20-21.

${ }^{166}$ De Re Strategica, 5, 7-10, p. 20. The guiding principle of the treatise is to make sure that the Byzantine territory suffers no harm.

${ }^{167}$ The importance of those border regions was known to the emperors, which resulted in the formation of small border semi-themes called kleisoura, A. KazHDAN, Kleisoura, [in:] ODB, vol. II, p. 1132. ${ }^{168}$ This is why the control over mountain passes was so crucial. The author of the source provides detailed instructions in this regard, De velitatione, 23, p. 231-233.

${ }^{169}$ Tactica, XVIII, 128, 627-629, p. 484-485.
} 
to return home $\mathrm{e}^{170}$. What is more, these tactics were employed both in pitched battles and in small-scale ambushes on raiding parties ${ }^{171}$. As a result, greed proved the typical reason for defeat. The Byzantine generals were aware of this mechanism and occasionally tried to set traps on the Arabs. Thus, the author of De velitatione instructs commanders to select some brave soldiers and dress them in civil clothes, so that they pretend to be farmers ${ }^{172}$. Such a group was sent (along with herds) to the vicinity of the Arab forces. At some distance from them, however, a strong unit of soldiers would wait in hiding to intercept the careless attackers.

Teresa Wolińska argues that there were two reasons for this strategy ${ }^{173}$. She points out that the priority of the Byzantine authorities was the defense of the fertile coastal territories, while the borderlands of the Empire were of little value due to the constant conflict with the Arabs ${ }^{174}$. What is more, in order to protect the interior of the state, the main aim was to destroy the foe and not to defend local inhabitants. Thus, generals delayed the attack until there were favorable circumstances to achieve both of the aforementioned objectives. Secondly, Leo the Wise observed that while the Arabs were capable fighters, they were unable to reform the line once their formation was broken in battle ${ }^{175}$. Thus, attacking undisciplined soldiers gave the best prospect of victory. All in all, one is left with the impression that Byzantine commanders occasionally treated the local population as bait.

Furthermore, as remarked above, the captives consumed part of the food supplies, and a detachment of soldiers had to guard them. Aware of this, Leo advises his generals to keep only strong and young captives during the siege of a city, while women, children and the elderly should be sent back ${ }^{176}$. The freed civilians were of no use for the besieged; on the contrary, they could occasionally do the Byzantines a favor. What is more, the defendants were less motivated to fight, since they expected good treatment in case of a swift surrender.

\section{Prisoners of war - source of information or tool of diversion?}

One could deduce from the previous part of the paper that prisoners were mainly a burden, unless commanders managed to deliver them safely to their territory. However, in some cases, the Byzantine generals knew how to utilize the captured

\footnotetext{
${ }^{170}$ De velitatione, $4,14-28$, p. 157-159. The strategy was as follows: firstly, take advantage of the fact that the enemy army is already tired as a result of the campaign; secondly, utilize the fact that part of the army is occupied with keeping an eye on the prisoners; finally, make use of the enemy's lowered morale (the soldiers would focus on the impending return home rather than on fighting further battles).

${ }^{171}$ De velitatione, 11, 13-31, p. 185.

172 De velitatione, $18,21-31$, p. 211-215.

${ }^{173}$ T. Wolıńska, Synowie Hagar. Wiedza Bizantyńczyków o armii arabskiej w świetle traktatów wojskowych z IX i X wieku, VP 35, 2015, p. 397-416.

${ }^{174}$ Ibidem, p. 413.

${ }^{175}$ Tactica, XVIII, 111, 538-540, p. 478-479; T. Wolı́́sKa, Synowie..., p. 409.

${ }^{176}$ Tactica, XV, 22, 134-135, p. 360-361.
} 
enemies to their advantage in yet different ways. Prisoners were taken not only to be enslaved or for ransom, but also to provide important information during the war. Most of the military manuals from the period in question stress that this was one of the most common and fundamental ways of determining what the enemy was planning, where he was stationed, and how strong he was. The advice to take prisoners in order to gain tactical information recurs on multiple occasions in the Tactica by Leo the Wise ${ }^{177}$. Similarly, the author of De velitatione lists raiding and taking captives among the basic duties of the trapezites ${ }^{178}$. It is worth mentioning that, according to both sources, it was the commander in chief who questioned the prisoners.

What is particularly striking, however, is that taking captives from enemy lines was emphasized more than protecting the citizens of the Empire. The author of De velitatione urges commanders to delay the attack on the Arabs until they break formation and start pillaging Byzantine farms and villages ${ }^{179}$. Thus, the prospect of capturing Hamdanid warriors, some of whom were well-informed about the strength of the army as well as its itinerary, must have been the key motivation of the Byzantines. Likewise, the author of the Praecepta Militaria points out that information acquired in this way had great impact on planning the campaign, decisions on when to give battle, and maintaining discipline in the Byzantine military camp $^{180}$. For instance, if the prisoners provided a general with credible information that there was only one enemy army ahead, he could afford more aggressive tactics as well as - if the lines were broken - a more audacious pursuit.

However, both sides of the conflict knew the mechanism in question and tried to use it to their advantage. This is why Leo the Wise warned his commanders to double the guards and the intelligence effort before the battle in order to intercept potential deserters from the Byzantine army - or enemy spies ${ }^{181}$. The author of De velitatione was likewise aware that if any of the Empire's soldiers were captured (as deserters or members of the reconnaissance squad), the whole military operation could come under dire threat ${ }^{182}$. What is more, even if such soldiers were set free or regained their freedom in any other way, the authors of military manuals advised the commanders to keep their eyes on them. If someone had been kept in captivity, the general should not appoint him to a garrison in a fortress or a guarding post in a military camp ${ }^{183}$. On the other hand, the Byzantines were always eager to accept deserters from the enemy army. The anonymous author of the Treaty on

\footnotetext{
177 Tactica, XVII, 31, 161-162, p. 403-404; XVII, 49, 273-275, p. 410-411.

${ }^{178}$ De velitatione, 2, 28-31, p. 153.

${ }^{179}$ De velitatione, 10, 17-19, p. 175.

${ }^{180}$ Praecepta Militaria, II, 3, 25-27, p. 25.

${ }^{181}$ Tactica, XIV, 25, 171-175, p. 304-305.

${ }^{182}$ De velitatione, 15, 13-15, p. 197-199.

${ }^{183}$ De Re Strategica, 9, 34-39, p. 30-31.
} 
Strategy advises treating enemy deserters well, although one should watch them carefully, even if they accepted Christianity or married Byzantine women ${ }^{184}$.

Leo the Wise was even less optimistic concerning the credibility of deserters. The emperor mentions twice in his Tactica that it is usually prisoners of war (i.e. those captured in combat) who deliver crucial and trustworthy information, not deserters ${ }^{185}$. On the contrary, Leo advises being suspicious of combatants who deserted their former masters, as deceit is likely to be involved ${ }^{186}$. This stratagem was in fact practiced by the Byzantines themselves, judging by the advice in the military manuals ${ }^{187}$. Leo mentions in his treaty that one can sometimes select brave volunteers who can let themselves get caught or feign desertion ${ }^{188}$. These individuals were to provide the foe with information in a way controlled by the Byzantines. One can presume that in the case of this stratagem, it was crucial that the movements of the Byzantine army should match the information given by the spy to the enemy (at least at the beginning), in order to protect his life.

The above-mentioned examples prove that prisoners of war were also of practical use for the commanders, especially during campaigns on enemy territory. Although captives could provide the army with credible and valuable information, it was not advisable to trust their account uncritically. Leo preferred to rely on the account of captured combatants, not on deserters; he was aware, however, that both could have been offered as bait.

\section{Captives as part of a marching army}

Whether soldiers or civilians, captives were often utilized as human shields by both Byzantine and Arab armies ${ }^{189}$. This maneuver was resorted to especially during marches through difficult and hostile terrain ${ }^{190}$. Although it could seem that this tactic was typical of the Hamdanids raiding the borderlands of the Empire, it is in fact the Byzantines who left us a detailed description concerning the role of prisoners in shielding the army ${ }^{191}$. Thus, Leo the Wise advises his generals to lead

\footnotetext{
${ }^{184}$ De Re Strategica, 41, 3-5, p. 120-121.

185 Tactica, XVII, 32, 166-168, p. 404-405; XX, 38, 199-200, p. 550-551.

186 The author of a younger source, namely the Sylloge Tacticorum, emphasizes this very strongly, Sylloge Tacticorum, XXVII, 1-3, p. 45-46.

187 Sylloge Tacticorum, LXXVII, 1-5, p. 99-100.

${ }^{188}$ Tactica, XVII, 13, 79-83, p. 398-399.

189 The most detailed description is provided in Leo's Tactica in book IX.

${ }^{190}$ One should also remember that both infantry and cavalry tactics underwent considerable evolution during the $10^{\text {th }}$ century. The square formation was frequent in march and in battle alike, E. McGeER, Infantry versus Cavalry: The Byzantine Response, REB 46, 1988, p. 137-141.

${ }^{191}$ Leading prisoners on the flanks offered some defense both against the attacks of the swift Bedouin light cavalry and the heavily armored Hamdanid riders. The square formation offered shelter within, and in most cases the prisoners were kept inside, E. MCGeER, Infantry..., p. 139-141.
} 
the captives at the flanks of the marching column in order to protect the Byzantine soldiers in case of enemy fire ${ }^{192}$. The emperor remarks that this may in fact make it possible to get the army safely across inaccessible terrain and deter the enemy from attacking. The above-mentioned instruction corresponds with the further order to kill the prisoners should the enemy attack the column ${ }^{193}$. Thus, the captives were utilized for blackmailing the enemy army and for encouraging it to parley or retreat. Perhaps this was the case in 950 AD: that year, Leo Phocas surprised Sayf al-Dawla, who was already returning to his territory after a successful campaign, carrying notable prisoners. John Scylitzes mentions that although the Byzantines were victorious, the Arabs managed to kill the captives. Although this is pure speculation, we may wonder if the domestic perhaps deliberately went out on a limb, choosing to inflict damage on the Hamdanid army rather than negotiate with the emir and watch him leave intact.

However, this was not the only way in which captives were used in service of the Byzantine army. Leo mentions in his treaty that captured enemy soldiers could be used to bolster the morale of the Byzantine troops. In the case of low-profile captives, it was particularly advisable to humiliate them in front of imperial soldiers and make them beg for their lives ${ }^{194}$. It is remarkable that whenever a wellbuilt and armored enemy soldier was captured, the generals' duty was to hide him from the eyes of the army. Both examples show that captives played an important role in Byzantine propaganda of success.

Sometimes, commanders would use the captured enemies for tasks they wanted to spare their own soldiers. When additional food or water supplies were found during the campaign, it was the prisoners who had to taste them first ${ }^{195}$. Leo deems this practice necessary, since the enemy would not infrequently leave poisoned food or drink with the hope that the campaigning army would fall for the trap. In some cases, the captured soldiers were used as messengers, since sending them to deliver certain information was safer than sending Byzantine soldiers ${ }^{196}$.

Among the many further ways of making use of captured enemy soldiers, one practice mentioned by Leo seems particularly noteworthy. The emperor notes that if the general knew to whom the captives belonged in the first place, he could use them to stir up turmoil in the enemy camp ${ }^{197}$. If the Byzantine commander released captives belonging to one enemy noble only, or spared his estates, this would certainly cast suspicion on the latter's loyalty in the eyes of the enemy. Eventually, this could make the target leader ally with the Byzantines and strengthen their own army.

\footnotetext{
${ }^{192}$ Tactica, IX, 48, 235-238, p. 172-173.

${ }^{193}$ Tactica, IX, 50, 246-249, p. 174-175.

${ }^{194}$ Tactica, XIII, 5, 20-25, p. 280-281.

${ }^{195}$ Tactica, XVII, 54, 305-307, p. 414-415.

${ }^{196}$ Tactica, XX, 23, 123-124, p. 544-545.

${ }^{197}$ Tactica, XX, 22, 113-118, p. 544-545.
} 


\section{$* * *$}

It is clear that taking prisoners of war during the $10^{\text {th }}$ century Arab-Byzantine conflict was an important aspect of any successful campaign, regardless of who was on the offensive. The captives could be used in many different ways by soldiers, commanders, and even by the state itself. For ordinary soldiers, prisoners mostly meant additional remuneration for their service, paid by the general still during the campaign or by slave traders back in the country. Commanders were especially eager to capture notable prisoners in hope of obtaining substantial ransom for them; besides, generals could use low-profile captives as a source of information or to increase the probability of success during the campaign. For the state, prisoners meant sheer profit, which could be utilized in propaganda, economy, and diplomacy. However, this could happen only if the victorious general was able to lead the captives safely onto Byzantine territory. The period between taking the prisoners and crossing the state border was a dangerous one, not only for the captives, but also for the captors. The instructions in the Tactica, De velitatione and Praecepta Militaria leave no doubt that both Muslim emirs and Byzantine commanders were aware that a marching army was more vulnerable to attacks if it included a large number of captives and carried considerable booty. Admittedly, the written sources only provide a limited number of examples referring to captured soldiers and civilians during the Arab-Byzantine conflict. However, the extant information clearly proves that the military treatises were based on day-to-day experience. Thus, the situations described must have been quite frequent during this turbulent period. The authors of the military manuals do not condemn taking prisoners in general; rather, they advise flexibility. The captives are perceived as a natural consequence of the war and as an element that may provide many benefits for the victorious army. However, under certain circumstances, prisoners were more of a threat than a profit for the whole operation; in such cases of danger, the commander was advised not to hesitate.

\section{Bibliography}

\section{Primary Sources}

Chronographiae quae Theophanis Continuati nomine fertur Liber V quo Vita Basilii Imperatoris amplectitur, ed. I. ŠEvčEnKo, Berlin-Boston 2011 [= Corpus fontium historiae Byzantinae, 42].

The Chronography of Gregory Abu'l Faraj 1225-1286, the Son of Aaron, the Hebrew Physician, Commonly Known as Bar Hebraeus, trans. E.A. Wallis Budge, Amsterdam 1976.

Constantine Porphyrogenitus, Three Treatises on Imperial Military Expeditions, ed. et trans. J.F. HALdon, Wien 1990 [= Corpus fontium historiae byzantinae, 28]. 
Constantini Porphyrogeniti imperatoris De cerimoniis aulae byzantinae libri duo, vol. I-II, ed. J.J. ReISKE, Bonn 1829-1830 [= Corpus scriptorum historiae byzantinae, 1].

Dìwān al-Amīr Abì Firās al-Hạmdānī, ed. M. AL-Tunjı, Damascus 1987.

Ecloga. Das Gesetzbuch Leons III. und Konstantinos' V., ed. L. Burgmann, Frankfurt 1983 [= Forschungen zur Byzantinischen Rechtsgeschichte, 10].

Histoire de Yahya-ibn-Sa'ïd d'Antioche, continuateur de Sa'ïd-ibn-Bitriq, ed. et trans. I. KRATCHKovsky, A.A. Vasiliev, Paris 1924 [= Patrologia orientalis, 18.5].

The History of al-Tabarī, vol. XXXVIII, The Return of the Caliphate to Baghdad, trans. F. RosenthaL, Albany 1985 [= Bibliotheca Persica].

The History of Leo the Deacon. Byzantine Military Expansion in the Tenth Century, trans. et ed. A.-M. Тацвот, D.F. Sullivan, Washington 2005 [= Dumbarton Oaks Studies, 41].

IвN AL-ATHIR, al-Kāmil fī at-Ta’rìkh, ed. M.Y. AL-DAQAQ, Beirut 1987.

Ibn Khordîdhben, Kitab al-Masalik wa'l-Mamalik, ed. M.J. DE GoeJe, Lugduni Batavorum 1889 [= Bibliotheca Geographorum Arabicorum, 6].

Ioannis Scylitzae Synopsis historiarum, ed. H. ThurN, Berolini 1973 [= Corpus fontium historiae byzantinae, 5].

John Skylitzes, A Synopsis of Byzantine History, 811-1057, trans. J. Wortley, Cambridge 2010.

Kronika Leona Gramatyka, [in:] Testimonia Najdawniejszych Dziejów Słowian. Seria grecka, V, Pisarze $z X$ wieku, trans. et ed. A. Brzóstкowska, Warszawa 2009, p. 68-91 [= Prace Slawistyczne, 127].

Leonis Diaconi Caloensis Historiae Libri Decem, ed. C.B. HASE, Bonnae 1828 [= Corpus scriptorum historiae Byzantinae, 3].

Novella of the Emperor John Concerning the Tax on Slaves Taken in War, [in:] E. McGeER, Sowing the Dragon's Teeth. Byzantine Warfare in the Tenth Century, Washington 1995 [= Dumbarton Oaks Studies, 33], p. 367-368.

Praecepta Militaria, [in:] E. McGeer, Sowing the Dragon's Teeth. Byzantine Warfare in the Tenth Century, Washington 1995 [= Dumbarton Oaks Studies, 33], p. 12-59.

De Re Strategica, [in:] Three Byzantine Military Treatises, trans. et ed. G.T. Dennis, Washington 1985 [= Dumbarton Oaks Texts, 9], p. 10-135.

The Taktika of Leo VI, trans. et ed. G. Dennis, Washington 2010 [= Corpus fontium historiae byzantinae. Series Washingtonensis].

A Tenth-Century Byzantine Military Manual. The Sylloge Tacticorum, trans. G. Chatzelis, J. Harris, London 2017 [= Birmingham Byzantine and Ottoman Studies].

Theophanes Continuatus, ed. I. BeKker, Bonnae-Lipsiae 1838 [= Corpus scriptorum historiae byzantinae, 31].

De velitatione, [in:] Three Byzantine Military Treatises, trans. et ed. G.T. DennIs, Washington 1985 [= Dumbarton Oaks Texts, 9], p. 137-239. 


\section{Secondary Literature}

Blondal S., The Varangians of Byzantium. An Aspect of Byzantine Military History, trans. B.S. BeneDIKZ, Cambridge 1978.

Bonner M., The Naming of the Frontier: Awāșim, Thughūr, and the Arab Geographers, "Bulletin of the School of Oriental and African Studies" 57, 1994, p. 17-24.

Cutler A., Gifts and Gift Exchange as Aspects of the Byzantine, Arab, and Related Economies, "Dumbarton Oaks Papers" 55, 2001, p. 247-278.

Dawson T., Byzantine Cavalryman c. 900-1204, Oxford 2009.

Dawson T., Byzantine Infantryman - Eastern Roman Empire c. 900-1204, Oxford 2007.

Durak K., Traffic across the Cilician Frontier in the Ninth and Tenth Centuries: Movement of People between Byzantium and the Islamic Near East in the Early Middle Ages, [in:] Proceedings of the International Symposium Byzantium and the Arab World. Encounter of Civilizations. (Thessaloniki, 16-18 December 2011), ed. A. Kralides, A. Gkoutzioukostas, Thessaloniki 2013, p. 141-154.

Eger A.A., Islamic Frontiers, Real and Imagined, "Al-'Usur Al-Wusta. The Bulletin of the Middle East Medievalists" 17, 2005, p. 1-6.

Friedman Y., The Nusayrī- 'Alawīs. An Introduction to the Religion, History, and Identity of the Leading Minority in Syria, Leiden 2010 [= Islamic history and civilization, 77].

Gibв H.A.R., Abū Firās, [in:] The Encyclopedia of Islam. New Edition, vol. I, Leiden-New York 1986, p. 119-120.

Grierson P., Nomisma, [in:] The Oxford Dictionary of Byzantium, vol. III, ed. A. Kazhdan et al., New York-Oxford 1991, p. 1490.

Grierson P., Solidus, [in:] The Oxford Dictionary of Byzantium, vol. III, ed. A. KazhdAN et al., New York-Oxford 1991, p. 1924.

Grierson P., Tetarteron, [in:] The Oxford Dictionary of Byzantium, vol. III, ed. A. Kazhdan et al., New York-Oxford 1991, p. 2026-2027.

Huart C., Lamas-Șū, [in:] The Encyclopedia of Islam. New Edition, vol. V, Leiden-New York 1986, p. 647.

Kaldellis A., Did Ioannes I Tzimiskes Campaign in the East in 974?, "Byzantion. Revue internationale des études byzantines" 84, 2014, p. 235-240.

Kazhdan A., Domestikos ton scholon, [in:] The Oxford Dictionary of Byzantium, vol. I, ed. A. KazHDAN et al., New York-Oxford 1991, p. 647-648.

Kazhdan A., Kleisoura, [in:] The Oxford Dictionary of Byzantium, vol. II, ed. A. Kazhdan et al., New York-Oxford 1991, p. 1132.

Kolia-Dermitzaki A., Some Remarks on the Fate of Prisoners of War in Byzantium $\left(9^{\text {th }}-10^{\text {th }}\right.$ Centuries), [in:] La liberazione dei 'captivi' tra cristianità e islam. Oltre La Crociata e il Ğihād. Tolleranza e servizio umanitario. Atti del Congresso interdisciplinare di studi storici, ed. G. Gipollone, Città del Vaticano 2000 [= Collectanea Archivi Vaticani, 46], p. 583-620.

Lounghis T.C., The Decline of the Opsikian Domesticates and the Rise of the Domesticate of the Scho-

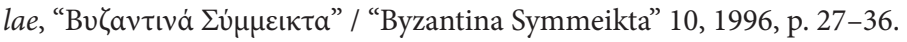


Mansouri M.T., Byzantium and the Arabs from the VII th to $I^{\text {th }}$ Century, "Mediterranean World / Mediterranean Studies" 20, 2010, p. 57-68.

McCormick M., Eternal Victory. Triumphal Rulership in Late Antiquity, Byzantium and the Early Medieval West, Cambridge 1986 [= Past and Present Publications].

McGeer E., Infantry versus Cavalry: The Byzantine Response, "Revue des études byzantines" 46, 1988, p. $135-145$.

McGeer E., Sowing the Dragon's Teeth. Byzantine Warfare in the Tenth Century, Washington 1995 [= Dumbarton Oaks Studies, 33].

Morrisson C., Cheynet J.-C., Prices and Wages in the Byzantine World, [in:] The Economic History of Byzantium. From the Seventh through the Fifteenth Century, ed. A.E. LAIou, Washington 2002, p. $816-878$.

NaKada K., The Taktika of Leo VI and the Byzantine Eastern Frontier During the Ninth and Tenth Centuries, "Spicilegium. Online Journal of Japan Society for Medieval European Studies" 1, 2017, p. $17-27$.

Niaki S.E.H.A., ChafjiRi H.S., The Common Themes of Prison Poetry in the Poems by Abu-Firas Al-Hamdani and Mas'od Sa'd Salman, "Journal of Applied Environmental and Biological Sciences" 5, 2015, p. 286-294.

Ostrogorski G., Dzieje Bizancjum, trans. ed. H. Evert-Kappesowa, ${ }^{3}$ Warszawa 2008.

Porteous J., Coins in History. A Survey of Coinage from the Reform of Diocletian to the Latin Monetary Union, London 1969.

Prosopographie der mittelbyzantinischen Zeit. Zweite Abteilung (867-1025), vol. VI, ed. R.-J. LiLIE et al., Berlin 2013.

Ramadan A., The Treatment of Arab Prisoners of War in Byzantium, $9^{\text {th }}-10^{\text {th }}$ Centuries, "Annales Islamologiques" 43, 2009, p. 155-194.

Simeonova L., In the Depths of Tenth-century Byzantine Ceremonial: the Treatment of Arab Prisoners of War at Imperial Banquets, "Byzantine and Modern Greek Studies" 22, 1998, p. 75-104.

Smythe D.C., Why Do Barbarians Stand Round the Emperor at Diplomatic Receptions?, [in:] Byzantine Diplomacy. Papers from the Twenty-fourth Spring Symposium of Byzantine Studies, Cambridge, March 1990, ed. J.S. Shepard, S. Franklin, Aldershot 1992 [= Society for the Promotion of Byzantine Studies publications, 1], p. 305-312.

SypiaŃski J., Arabo-Byzantine Relations in the $9^{\text {th }}$ and $10^{\text {th }}$ Centuries as an Area of Cultural Rivalry, [in:] Proceedings of the International Symposium Byzantium and the Arab World. Encounter of Civilizations. (Thessaloniki, 16-18 December 2011), ed. A. Kralides, A. Gkoutzioukostas, Thessaloniki 2013, p. 465-478.

Tацвот A.-M., Sullivan D.F., Introduction, [in:] The History of Leo the Deacon. Byzantine Military Expansion in the Tenth Century, trans. et ed. IIDEM, Washington 2005 [= Dumbarton Oaks Studies, 41], p. 1-52.

Toynbee A., Constantine Porphyrogenitus and His World, London-New York 1973.

Treadgold W., A History of the Byzantine State and Society, Stanford 1997.

VAsiliev A.A., Byzance et les Arabes, vol. II, La Dynastie macédonienne, 867-959, Bruxelles 1950.

Wolı́́ska T., Synowie Hagar. Wiedza Bizantyńczyków o armii arabskiej w świetle traktatów wojskowych z IX i X wieku, "Vox Patrum. Antyk Chrześcijański" 35, 2015, p. 397-416. 


\begin{abstract}
For the Byzantine emperors of the $10^{\text {th }}$ century, the eastern front was the crucial one, due to the constant struggle with the Abbasid Caliphate. In the course of this conflict - from which Byzantium emerged victorious - the capturing and enslaving of soldiers and civilians alike was an everyday reality. The main objective of this paper is to define the role of prisoners of war in the strategy and tactics of Byzantine generals. First, I will attempt to determine whether the latter treated the captives as a potential gain under various aspects (i.e. financial, prestige-related, or diplomatic). Next, I will focus on those situations in which prisoners were nothing more than a burden. With the help of narrative sources and military manuals, I will try to clarify why both sides occasionally decided to execute their captives in certain episodes of the $10^{\text {th }}$ century Arab-Byzantine conflict. Finally, I will specify how Byzantine generals made use of prisoners in order to get the upper hand over their Arab rivals.
\end{abstract}

Keywords: Arab-Byzantine conflict, civilian captives, military captives.

\title{
Szymon Wierzbiński
}

Politechnika Łódzka

Wydział Zarządzania i Inżynierii Produkcji Instytut Nauk Społecznych i Zarządzania Technologiami

Zakład Nauk Humanistycznych

ul. Piotrkowska 266

90-924 Łódź, Polska/Poland szymonwierzbinski@op.pl 